\title{
Korpus, keel ja keelekasutus
}

"Lähivõrdlusi. Lähivertailuja” ilmub nüüd juba 24. korda. See on kuues kord praeguses vormis, Eesti Rakenduslingvistika Ühingu väljaandena. Oleme uhked ja õnnelikud selle viimastel aastatel üha mahukamaks muutunud rahvusvahelise ajakirja üle, kus ilmub jätkuvalt artikleid soome, eesti ja teiste soome-ugri keelte kasutamisest, õppimisest ja õpetamisest. Arvame, et väljaanne on leidnud oma koha ja soome-ugri keelte rakenduslikust uurimisest huvitunud on leidnud "Lähivõrdlused", kuid mõistagi on väga teretulnud ka kõik uued lugejad ja kirjutajad.

Üks osa 24. numbri artiklitest põhineb taas kord "Lähivõrdlustega" tihedalt seotud konverentsi ettekannetel, mis peeti 2013. a sügisel Soome Rakenduslingvistika Ühingu (AFinLA) sümpoosioni raames soomeugri keeli sihtkeelena uuriva VIRSU-võrgustiku korraldatud töötoas. Teine osa artiklitest tutvustab muid uurimistulemusi.

Nii nagu see on olnud paljudes varasemates "Lähivõrdluste" artiklites, lähtuvad mitme artikli autorid ka nüüd korpusainestikust. Pille Eslon analüüsib Tartu Ülikooli kirjakeele korpuse ja eesti vahekeele korpuse põhjal adverbi sisaldavaid konstruktsioone eesti ilukirjandusja õppijakeeles. Eesti ilukirjanduskeeles on adverbikonstruktsioonidel tähtis roll teksti sidususe ja sujuvuse loomise vahendina, õppijakeeles on nende kasutus marginaalne ja stereotüüpne. Kuigi mõlemas keelevariandis kasutatakse ühtesid ja samu konstruktsioone, on õppijakeele leksikaalne ja morfosüntaktiline varieerumine palju piiratum.

Outi Toropainen, Nina Reiman ja Marja Seilonen on kasutanud uurimismaterjalina Jyväskylä ülikooli Cefling-korpust. Toropaise artikkel käsitleb ülesandes kasutatud sõna või samasse sõnaperre kuuluva sõna kordumist õppijate tekstides. Reiman uurib transitiivsust ja ülesande mõju, seetõttu on tema tulemused hästi võrreldavad Toropaise 
omadega. Seilonen omakorda lähtub õppijate taustast ja on valinud uurimiseks tervishoiutöötajate keelekasutuse.

Tuija Määttä jätkab rootsikeelsete soome keele õppijate keelekasutuse kaardistamist ICLFI-korpuse (International Corpus of Learner Finnish) põhjal ja pakub sedasi võrdlusmaterjali teistele samalaadsetele uurimustele. Ilmari Ivaska ainestikuks on LAS2-korpuse edasijõudnud soome keele õppijate keelekasutus, täpsemalt eksamivastused kui üks akadeemilise kirjutamise tekstiliik. Artiklis võrreldakse tüüpilist akadeemilise kirjutamise võtet, s.o võimalikkuse väljendamist võimaverbi abil edasijõudnud õppijate ja emakeelsete soome üliõpilaste tekstides.

Ekspressiivverbe, mida Marjatta Jomppanen käsitles "Lähivõrdluste" 21. numbris, analüüsib nüüd Maria-Magdlena Jürvetson. Tema uurimismaterjal ja lähtekoht on siiski teine: põhiküsimus on, kuidas kaardistada küsitlusmeetodi abil emakeelsete keelekasutajate arusaamu ekspressiivverbide tähendustest ja tähendusvarjunditest. Nii saadaks täpsemat ja ajakohasemat teavet, kui mistahes sõnaraamat võib anda, mis toetab nii õppijaid kui õpetajaid ekspressiivverbide tõlgendamisel.

Leena Niiranen kirjutab tähtsal, kuid vähe tuntud teemal: Norra kveeni keele elustamisest lasteaedades, kus on kasutatud keelepesameetodit. Artiklis arutletakse keelepesameetodi ja selle õnnestumise eelduste üle Yrjö Engeströmi tegevusteooriast lähtudes.

Pirkko Muikku-Werner käsitleb nagu "Lähivõrdluste" 22. (koos Maria Heinosega) ja 23. numbriski eesti keele mõistmist soome keele põhjal. Lisaks sarnasusele on oluline kotekst, mille mõju võib olla nii positiivne kui negatiivne.

Käesolevas numbris leidub sarnaselt eelmistele nii artikleid kui ka ülevaateid. Kirjutised on rühmitamata, sest kõigi puhul on järgitud teadusartikli retsenseerimis- ja toimetamispõhimõtteid.

Täname autoreid mitmekesiste artiklite ja retsensente väärtuslike kommentaaride eest, mida tulemuslikult kasutasime. Toimetuse tänu majandusliku toetuse eest kuulub jätkuvalt Alfred Kordelini sihtasutusele, Soome-Ugri Kultuuriseltsi sihtasutusele ning Eesti Haridus- ja 
Teadusministeeriumi rahastatavale riiklikule programmile "Eesti keel ja kultuurimälu II”. Peame eriti oluliseks, et ajakiri "Lähivõrdlusi. Lähivertailuja” ilmub Eesti Rakenduslingvistika Ühingu egiidi all. Aitäh selle eest.

Tallinnas, Viinis ja Turus

Annekatrin Kaivapalu, Johanna Laakso, Kirsti Siitonen ja Katre Õim 